\title{
Objectives of International Criminal Law and Jurisdiction of ICC
}

\author{
Saqib Jawad \\ International Islamic University, Islamabad, Pakistan \\ Civil Judge/Judicial Magistrate Islamabad, Pakistan
}

Copyright (C) 2015 Horizon Research Publishing All rights reserved.

\begin{abstract}
Although roots of criminal prosecutions are traced back in the $17^{\text {th }}$ and $18^{\text {th }}$ century but newly emerged discipline of international law namely international criminal law gained its scope after adoption Rome Statute. However, statute has not yet been universally accepted and various discrepancies have been raised by various states regarding the Jurisdiction and applicable procedure of International Criminal Court (ICC). Prior to the establishment of ICC, initially various international tribunals were established for the prosecutions of perpetrators of genocide, war crimes, crimes against humanity, and aggression, particularly after World War II. However, the prosecutions were subjected to serious criticism not only by the states representing the accused persons rather by the prosecuting states as well, on the grounds that all the prosecutions were partial in nature and even the same crimes were committed by the prosecution states but not a single individual was subjected to prosecutions from within the prosecuting states. Thereafter, instances have been reported of individual prosecutions till two decades back when again certain individuals including the heads of states were prosecuted for their alleged crimes, including genocide, war crimes, and crimes against humanity. All these events and previous prosecutions resulted in establishment of ICC, but the statute has not yet been ratified by most of the states on a number of reasons and the most relevant of them is the jurisdiction of the court. Although, all the concepts and types of jurisdiction are not controversial but most of the concerns have been shown regarding the universal jurisdiction of ICC, and all the related concepts which provide the action of a state outside the jurisdiction of a states.
\end{abstract}

Keywords Crimes Against Humanity, General Assembly, Genocide, International Criminal Court, International Criminal Justice System , International Criminal Law, International Human Rights Law , International Humanitarian Law , Perpetrators , Security Council, War Crimes, World War

\section{Introduction}

International Criminal Law (ICL), has been designed to achieve certain goals and it is often said that ICL is not good or bad in itself, rather it is the way in which it is implemented which makes it a good or bad legal system. Moreover, as International Criminal Justice System (ICJS) differs from the municipal or domestic legal systems, so the objectives of both legal systems also differ ${ }^{1}$.

\section{Background}

Before going into the details of the subject topic it seems expedient to have a short look at the background and development of ICL in general and ICJS in particular.

Crimes have often been reported to be committed during war, and mostly there is chance of innocent people to be killed in war, hence as a general rule all wars are unjustified ${ }^{2}$. It has been reported in history that prosecution of war criminals existed even at the time of ancient Greeks. But as far as the codification of modern international criminal law is concerned, the first law which has been codified is the Lieber Code, prepared by Columbia University professor Francis Lieber, which was applied by Abraham Lincoln to the Union Army during the American Civil War for their war crimes, particularly regarding humiliation, pillage, raping civilians, inhuman and degrading treatment of prisoners of wars, and such other atrocities ${ }^{3}$. The words given to all the above-mentioned crimes are new, however the concepts are ancient and are traced back to the initial clashes between human beings ${ }^{4}$.

Then the first international trial which was conducted under ICL, is said to be of Peter von Hagenbach, carried out in 1474 for the alleged atrocities committed by him ${ }^{5}$. Then

\footnotetext{
${ }^{1}$ Robert Cryer, Hakan Friman, Darryl Robinson, Elizabeth Willmshurts, An Introduction to International Criminal Law and Procedure, Cambridge, Cambridge University Press, (2010), 22.

2 Larry May, Aggression and Crimes against Peace, (Cambridge: Cambridge University Press, 2008), 6.

${ }^{3}$ William A. Schabas, An Introduction to International Criminal Court, Cambridge, Cambridge University Press, (2007), 1.

4 Adam Jones, Genocide: A Comprehensive Introduction, (Park Square: Routledge, 2006), 3.

${ }^{5}$ William A. Schabas, An Introduction to International Criminal Court,

Cambridge, Cambridge University Press, (2007), 1.
} 
the treaty of Serves executed in 1920, also played an important role in the development of this branch of international law and it was the time when the need for the establishment of an independent International Criminal Court, (ICC), was emphasized ${ }^{6}$.

Besides, we know that after World War I, The Covenant of the League of Nations was signed, and after World War II, execution of Nuremberg and Tokyo trials and establishment of ad hoc international tribunals further developed ICJS.

In October 1945, under these trials initially 24 Nazi members tried, out of them 19 were convicted, and out of these 19,10 were given death penalties ${ }^{7}$. However, number of questions was raised over the bonafide of the prosecutors and ultimately trials were not considered a success ${ }^{8}$.

Although, it is alleged that these Nazi members were tried on the pressure of allied powers and execution was also the result of the same, but the ultimate conviction of these 19 people is very important in the development of international criminal law. But initially the jurisdiction of this tribunal was confined to crimes against peace, war crimes and crimes against humanity ${ }^{9}$.

In this process, an International Law Commission (ILC) was established, the primary purpose of which was the progressive development and the codification of international law, which also played its role in the development of international criminal law ${ }^{10}$. In the late 1980 's the General Assembly asked ILC to look into the possibility of establishment of an international criminal court in order to enforce the code of human rights and for assurance of peace and security of the mankind ${ }^{11}$. Later on, the General Assembly (GA), resolution regarding the adoption of the Rome Statute of International Criminal Court (ICC) was brought and sixty ratifications of the state parties were required for the statute to become enforced. All these conditions were met and the Rome statute of ICC became enforced on $1^{\text {st }}$ July $2002^{12}$.

\section{Objectives of International Criminal Law}

As far as the objectives and aims of international criminal law are concerned, these can be determined according to the references and interpretations made by different international courts and tribunals. For instance, some of these objectives have been asserted by International Criminal

\footnotetext{
Ibid, 4.

7 Ibid. 6.

8 Robert Cryer, Prosecuting International Crimes: Selectivity and the International Criminal Law Regime, (Cambridge, New York, Melbourne, Madrid, Cape Town, Singapore, São Paulo, Cambridge University Press, 2005), .

9 William A. Schabas, An Introduction to International Criminal Court, Cambridge, Cambridge University Press, (2007), 1.

10 Ibid, 8-9.

11 Robert Cryer, Prosecuting International Crimes: Selectivity and the International Law Regime, (Cambridge, New York, Melbourne, Madrid, Cape Town, Singapore, São Paulo, Cambridge University Press, 2005), 57.

${ }_{12}$ William A. Schabas, An Introduction to International Criminal Court, Cambridge, Cambridge University Press, (2007), 21-22.
}

Tribunal for Yugoslavia, (ICTY). The first objective or aim of international criminal law asserted by ICTY is that of the theory of retribution. This theory of punishment is associated with a famous jurist Immanuel Kant. According to him and his disciples in this theory, it is necessary to punish criminals, because of the fact that it will bring future benefits for the society. But it was held by ICTY in Aleksovski case, that the objective to inflict punishment is not the revenge from the criminal, rather the primary purpose is expressing outrage at the crimes. Moreover in Todorovic'Case, the principle has been laid down by ICTY that a fair and balanced approach should be adopted regarding the punishment, which clearly shows that it should be proportional according to the nature of crimes ${ }^{13}$.

The second main objective asserted by ICTY is of deterrence. Jeremy Bentham is the founder of this theory of punishment and he and other jurists have base this theory on utilitarian approach, and they call it the best justification of punishing a criminal, which also speaks about the future benefits of the punishment, that through the implementation of this theory and deterrence other criminals will be prevented from commission of crimes, and on the other hand, rest of the population and ordinary citizens will be protected from these criminals ${ }^{14}$.

But certain other jurists have severally criticized this theory of punishment. They are of the view that no limits have been prescribed for this type of punishment, hence being unlimited in nature it may not be justified because of inflicting unnecessary punishment at several places. Moreover by creating deterrence innocent people may also be prosecuted and punished in consequence ${ }^{15}$.

Besides these two main theories of punishment, sometimes some other objectives are also referred as objectives of international criminal law.

At one place after examining the trials of Yugoslavia, Rwanda, and Uganda, Golash, the author has finally concluded that punishment is not a sufficient deterrent for preventing the international crimes ${ }^{16}$.

According to a newly emerged $18^{\text {th }}$ century concept, the basic aim of international criminal law is the reformation of the offender. Modern human rights activists widely support this notion and say that a criminal may be reformed, and if such is the case then the primary purpose of punishment should be to reform him accordingly. This was practiced in Erdemovic case, who being a young Bosnian Croat, and founded involved in Bosnian massacre was sentenced to a short term of five years imprisonment, due to his young age and capability of reformation ${ }^{17}$.

Another relevant objective closely associated with the

\footnotetext{
${ }^{13}$ Robert Cryer, Hakan Friman, Darryl Robinson, Elizabeth Willmshurts, An Introduction to International Criminal Law and Procedure,23-25.

${ }_{14}$ Ibid, 26,27.

${ }_{16}^{15}$ Ibid.

16 Ed. Larray May, Vanderbilt University and Centre for Applied Philosophy and Public Ethics, International Criminal Law and Philosophy, (Cambridge, New York, Melbourne, Madrid, Cape Town, Singapore, São Paulo, Delhi, Dubai, Tokyo: Cambridge University Press, 2010), 10.

${ }^{17}$ Robert Cryer, Hakan Friman, Darryl Robinson, Elizabeth Willmshurts, An Introduction to International Criminal Law and Procedure, 28-29.
} 
former is that of denunciation or education. According to this theory, arrest of the offender and his trial is a chance for the community for communication with him and making him understand the wrong done by him and the way in which he can make himself right in future through educating him in this regard ${ }^{18}$.

Moreover, there are some other objectives and some of them are specifically associated with international criminal law.

For instance, justice for the victim party is a primary objective of every criminal legal system, and same is the case with international criminal law. It was held in Nikolic case by ICTY that the punishment should be of such nature which will bring justice for all those persons who are victims of the crimes ${ }^{19}$.

Another objective can be inferred of recording history which will tell the truth to the coming generations regarding the facts which already occurred. An additional advantage of which will be that the judgments of international courts and tribunals will be in narrative form and a sort of precedents will be available for any future reference by any judicial body. But on the other hand, if the history has not been recorded properly then this fact will result in lengthy judgments of these courts and tribunals ${ }^{20}$.

Incapacitation of the criminal from the commission of crime is also an objective of international criminal law, which says that by keeping the criminal in detention he will be prevented from the commission of a crime. But this objective is future based, and by applying this type of theory one may not punish a person for a wrong already done by him, rather his punishment is based on the presumption of a criminal act which will be done in future, and by applying this, one may be called to punish a person for a thing which he has not done ${ }^{21}$.

It has also been asserted the main objective of international criminal law is, post conflict reconciliation, which says that peace will be established in a case where justice has been done to the victim party, as the phrase is often expressed that "no peace without justice". But again this notion has been criticized on the fact that, the prosecution between two conflicting parties will further cause the conflict and will not benefit in reconciliation of the parties $^{22}$.

It has also been held that international criminal trials contribute in promoting political reconciliation and will ultimately change the moral and social condition for law in the societies ${ }^{23}$.

It is also said that in international criminal law, judges operating at a distance from their states will be saved from any kind of influence or bias for such element, although at

\footnotetext{
18 Ibid, 29-30.

19 Ibid, 30-31.

${ }^{20}$ Ibid, $31-32$

${ }^{21}$ Ibid, 28.

22 Ibid, 33-34

23 Ed. Larray May, Vanderbilt University and Centre for Applied Philosophy and Public Ethics, International Criminal Law and Philosophy, (Cambridge, New York, Melbourne, Madrid, Cape Town, Singapore, São Paulo, Delhi, Dubai, Tokyo: Cambridge University Press, 2010), 11.
}

times judges were alleged to be biased in certain matters. Moreover, while sitting at the international level they will be representatives of their own communities, states or nations and another advantage is that they will be more familiar with the relevant law, unlike the judges playing their role at the domestic level ${ }^{24}$.

Above all, after going through all these objectives, is the objective of fair trials. This is the primary requirement under international criminal law, international human rights law, and international humanitarian law, according to which every human being is entitled for the right of fair trial. As denying the right to fair trial under the provisions of Geneva Conventions 1949 is a war crime, and same principle is applicable according to additional protocol 1 of the four Geneva Conventions, and the Rome Statute of International Criminal Court ${ }^{25}$.

The principle of fair trial is the main reason behind the international prosecution and even behind the establishment if independent international criminal court and other ad hoc tribunals, because national prosecutions of the war criminals failed to provide adequate remedy to the victims. This very fact was noted by Kofi Annan, while speaking in 1998, in his address to the Rome Conference that adopted the International Criminal Court Statute, when he said:-

"Gradually the world has come to realize that relying on each State or army to punish its own transgressors is not enough. When crimes are committed on such a scale we know that the State lacks either the power or the will to stop them. Too often, indeed, they are part of a systematic State policy, and the worst criminals may be at the pinnacle of State power"...

So international criminal law is a legal system in which fair and independent trials are to be conducted by the international community and the purpose of the establishment of international criminal court is the same.

\section{Jurisdiction}

In simple terms jurisdiction has been defined as "Power of the State to regulate affairs pursuant to its laws" $" 26$. This concept of jurisdiction is particularly pertaining the jurisdiction in international matters. The broader concept of jurisdiction has been covered under public international law, but here we are concerned with the exercise of jurisdiction in international criminal law. Who is the power to prosecute is an important question to be settled under international law and mostly it entirely depends upon the process under which prosecution is being conducted ${ }^{27}$.

The idea of the exercise of jurisdiction has been expressed

\footnotetext{
${ }^{24}$ Robert Cryer, Hakan Friman, Darryl Robinson, Elizabeth Willmshurts, An Introduction to International Criminal Law and Procedure, 28-29.

${ }^{25}$ Ibid.

${ }^{26}$ Ibid, 43

27 Jason Ralph, Defending the Society of States: Why America Opposes the International Criminal

Court and its Vision of World Society (New York: Oxford University Press, 2007), 55.
} 
in the Rome statute of International Criminal Court. Article 19 of the statute determines the scope of the court's authority, whereas Article 17 prescribes the principle of admissibility, or in ordinary terms it is called as the principle of first bite of apple. This principle lays down the first step in the exercise of jurisdiction in the terms that the courts at the national or domestic level have the first right to exercise the jurisdiction. The international body or the jurisdiction can be exercised by the judicial bodies at the international level only in the case where the national courts are unwilling or for any other reasons are reluctant to exercise the jurisdiction upon the criminals. Moreover, Article 5 of the statute further restricts the jurisdiction of ICC by the fact that four types of crimes have been mentioned in this Article which fall in the jurisdiction of ICC, and in this way the subject matter jurisdiction of ICC has also been determined ${ }^{28}$. However we can debate the issue in the coming discussion while discussing these crimes in details, as to whether there is any formal hierarchy among these four crimes which should be recognized while exercising such a jurisdiction or all the crimes are of equal status?

One thing has been cleared regarding the sources to be applied under Article 21 of the statute which states that:-

\section{The Court shall apply:}

(a) In the first place, this Statute, Elements of Crimes and its Rules of Procedure and Evidence;

(b) In the second place, where appropriate, applicable treaties and the principles and rules of international law, including the established principles of the international law of armed conflict;

(c) Failing that, general principles of law derived by the Court from national laws of legal systems of the world including, as appropriate, the national laws of States that would normally exercise jurisdiction over the crime, provided that those principles are not inconsistent with this Statute and with international law and internationally recognized norms and standards.

2. The Court may apply principles and rules of law as interpreted in its previous decisions.

3. The application and interpretation of law pursuant to this article must be consistent with internationally recognized human rights, and be without any adverse distinction founded on grounds such as gender, as defined in article 7, paragraph 3, age, race, colour, language, religion or belief, political or other opinion, national, ethnic or social origin, wealth, birth or other status.

It means that unlike Article 38 of the Charter of the UN, a formal hierarchy has been set up by the statute for the applicable sources while proceeding with a trial ${ }^{29}$.

\footnotetext{
28 Ibid.

${ }^{29}$ Ciara Damgaard, Responsibility for Core International Crimes Individual Criminal, (Denmark: Springer-Verlag, 2008). 44.
}

\section{Temporal (ratione temporis) jurisdiction}

The first principle of jurisdiction mentioned in the Rome statute of ICC is that of temporal jurisdiction, which lays down that the court will have jurisdiction only in the matters and crimes which took place after the entry into force of the Rome statute and the matters which occurred prior to that period will not be covered by the statute, meaning thereby that the statute will have no retrospective effect. The principle has been laid down in Article 11(1) of the statute. Here a famous case of Lubanga was referred to ICC for adjudication, and the question before the trial chamber was that whether the court has jurisdiction in this matter or not, as far as the temporal principle of jurisdiction is concerned. Finally, the issue was decided that the crimes requiring action were committed by Mr. Thomas Lubanga Dyilo between July 2002 and December 2003, which were committed after the entry into force of the statute and the same were under the jurisdiction of the court and consequently the jurisdiction was exercised ${ }^{30}$.

But in some cases difficulties may arise, for instance in the cases of continuous nature the determination of the temporal principle of jurisdiction will be difficult. Like forced disappearance or expulsion which is a war crime under the Geneva Conventions, and if the disappeared population is being prevented to come back in their hometown, then what will be status of that crime, if it was started prior to the entry into force of the statute and lasts after such date ${ }^{31}$.

\section{Types of Jurisdiction}

After analyzing the basic principles of jurisdiction, some of the main kinds of jurisdiction are as follows:-

\section{Legislative Jurisdiction}

This type of jurisdiction shows the principle and authority of a state to pass laws which may have bearing on the conduct of people. Some states have argued that they are entitled to pass laws that may have such bearing throughout the globe, but on the other hand we know that principle of non-intervention is the fundamental principle of international law, and in this context the exercise of this type of jurisdiction has been prohibited under the principle of non-intervention ${ }^{32}$.

\section{Adjudicative Jurisdiction}

This is the jurisdiction of a state to enforce its laws in all the matters brought before that state. In this context, states may pass judgments upon the crimes or matters which took place abroad, but again by enforcing such judgments

\footnotetext{
${ }^{30}$ William A. Schabas, An Introduction to International Criminal Court, 65-66.

31 Ibid.

32 Robert Cryer, Hakan Friman, Darryl Robinson, Elizabeth Willmshurts,

An Introduction to International Criminal Law and Procedure, 43-44.
} 
integrity of the other state may be affected ${ }^{33}$.

\section{Executive Jurisdiction}

By executive jurisdiction the enforcement of the legal process is meant, and such process may be enforced or implemented coercively, for instance search, seizure, and arrest etc. But again the process may violate the principle of non-intervention where such enforcement is being done outside the territory of that particular state. Upon this issue the verdict came in the Lotus case where it was decided that "Failing the existence of a permissive rule to the contrary it may not exercise its power in any form in the territory of another State". In Eichmann case, Israel also accepted the principle elaborated in the Lotus case but even then court did not declined to exercise jurisdiction ${ }^{34}$.

Moreover, there are two more principles of jurisdiction which are most important because these two principles are almost agreed upon among the jurists of international law.

\section{Territorial Jurisdiction}

This principle of jurisdiction has been described in Article 12 (2) (A) of the Charter of the International Court of Jurisdiction, and is the least controversial principle of jurisdiction in international law. According to this principle, a state shall have a right to exercise its jurisdiction over all the events occurring on its territory which shall also include the ships and aircrafts which are registered in that state ${ }^{35}$.

There are two main aspects of territorial jurisdiction under international law:-

\section{Objective Territorial Jurisdiction}

If an offence is originated in one state and is completed in another state, then the state in which the act was originated shall have jurisdiction on the ground of objective territorial principle. For instance, if a rocket is fired from one state at the territory of another state then the state from which the rocket is fired may exercise jurisdiction on this ground $^{36}$

\section{Subjective Territorial Jurisdiction}

According to this principle, a state shall have jurisdiction in the territory of a state where an act has been completed. In the former example, the state in the territory of which the rocket was fired shall have jurisdiction ${ }^{37}$.

\section{The Nationality Principle of Jurisdiction}

As mentioned under the territorial head of jurisdiction, principle of nationality jurisdiction has been divided into two main branches:-

\footnotetext{
33 Ibid, 44.

34 Ibid.

35 Ibid, 46.

36 Ibid.

37 Ibid.
}

\section{Active Nationality Principle}

According to this principle states are given power to legislate for their own nationals even when they are abroad. International Criminal Court is competent to exercise jurisdiction over the nationals of a state party under Article 12(2)(b), of its statute. But today prosecutions are seen to be based on the principle of territory rather than nationality. The exceptions to exercise of jurisdiction over the nationals include, exclusion of jurisdiction over the nationals under eighteen years of age, and over the persons immune from prosecutions, as enumerated under Article 27, and 98 of the Rome Statute ${ }^{38 .}$

\section{Passive Nationality Principle}

Passive nationality jurisdiction is exercised when a crime is committed against the nationals of a state when they are abroad. But this type of jurisdiction is controversial, as in Lotus case all the judges were of the opinion that such a principle was contradictory to the principles of customary international law ${ }^{39}$.

But there are a few exceptions to the general rules of exercise of jurisdiction over nationals. Firstly, persons under the age of eighteen years are explicitly excluded from the jurisdiction of the court. Second is the exclusion of the jurisdiction over persons enjoying any form of immunity including diplomats and personnels of intergovernmental organizations. Thirdly, court cannot proceed in a case which leads one of the parties to an act inconsistent according to the agreements reached with a third state. Finally, the court cannot exercise jurisdiction over a case which has been excluded by the Security Council ${ }^{40}$.

\section{Protective Principle}

A state may assert jurisdiction on protective principle of jurisdiction over the activities that threaten the security of that state, for instance espionage, disclosing and selling the secrets of the state, counterfeiting the currency of that state and the like cases. The jurisdiction may also be exercised over the act of aggression, as it was alleged in Eichmann case by Israel, but the same was rejected because at the time of commission of these acts Israel was not existing 41 .

Same principle has been asserted by the Dutch Cour de Cassation in Rohrig, Brunner and Heinze in 1950. While in Eichmann, the protective principle was mixed with other principles of jurisdcition such as passive nationality and universality. From the above cases it seems that the principle can be applied over all crimes including the crime of aggression ${ }^{42}$.

${ }^{38}$ William A. Schabas, An Introduction to International Criminal Court, 71.

${ }^{39}$ Robert Cryer, Hakan Friman, Darryl Robinson, Elizabeth Willmshurts,

An Introduction to International Criminal Law and Procedure, 49.

${ }^{40}$ William A. Schabas, An Introduction to International Criminal Court, Cambridge, Cambridge University Press, (2007), 73-75.

${ }^{41}$ Robert Cryer, Hakan Friman, Darryl Robinson, Elizabeth Willmshurts,

An Introduction to International Criminal Law and Procedure, 50.

${ }^{42}$ Ibid, 77. 


\section{Treaties and Universal Jurisdiction}

Universal jurisdcition is the most complicated, confusing and controversial concept of the international criminal law, and that is mostly because of the reason that certain states had excercised or intend to excercise the same for their personal interests. That is why some of the international law experts deny the exixtence of universal jurisdiction at all. However, according to majority point of veiw this type of jurisdiction is excercised irespective of the territory where the crime is committed, nationality of the perpeprator or the accused, or the state or nationality of the victim, and this type of jurisdcition is excercised in cases of piracy, genocide, war crimes, crimes against humanity and torture ${ }^{43}$. The concept of universal jurisdcition has been further devided into two sub-categories:-

Pure/Absolute:- it is also known as universal jurisdcition in absentia and is excercised irrespective of the fact whether the accused is present in the territory of the state excercising such jurisdcition or not.

Conditional:- It is also known as universal jurisdiction in presence, and is excercised when the perpeprator or the accused is present in the state excercising such jurisdcition ${ }^{44}$. Altough, some of the states have restricted themselves to the extent of pure universal jurisdcition but the concept shows lack of trust particularly when the states have agreed to prosecute the major international crimes and the same has been endorsed by customary international law.

\section{Subject Matter Jurisdcition}

Primarily, the jurisdiction of International Criminal Court has been restricted over four categoris of crimes and those are, genocide, crimes agaisnt humanity, war crimes and aggression $^{45}$. All the aforementioned offences are having their own respective definitions and mostly are concerned with international humanitarian law (IHL), because the same deals with the conduct of war or rules of war $^{46}$. In the preamble of the statute of International Criminal Court, as well as under Article 5 of the statute, these crimes have been termed as, "the most serious crimes of concern to the international community as a whole". They are also called elsewhere as "unimaginable atrocities that deeply shock the concience of humanity". Ordinarliy, these crimes are not prosecuted under ordidunary criminal justice system for a number of reasons. That is why only these four categories of crimes have been brought within the domain of ICC, otherwise there may be most serious crimes than these, but domestic criminal justice system may be more effecient to address this issue. For instance, terrorism may invole hundreds of deaths, but ordinarily domestic system of every state has become effecient to address the issue, hence, not

\footnotetext{
43 Ibid, 50.

44 Ibid, 44.

45 Ibid.

${ }^{46}$ Leslie Alan Horvitz and Christopher Catherwood, Encyclopedia of war crimes and genocide, (New York: Facts On File, Inc, 2006), 1.
}

requires involvement of international criminal justice system $^{47}$.

Although, no formal heirarchy has been laid down among these four categories of crimes, but customary international law, decisions of international criminal tribunals and the statute itself suggests that some sort of heirarchy exists even among these crimes. "Opt out" mechanism present in the statute, imposing major penalty over a crime of genocide and major over war crimes by the international tribunals, and prosecutors considering it beneficial for the accused to plead guilty for war crimes or crimes against humanity instead of genocide further affirms that some sort of heirarchy exists among these crimes in international criminal justice system ${ }^{48}$.

\section{Triggering the Jurisdcition}

The jurisdiction of the ICC can be triggered in the follwing ways:-

\section{By a State Party}

A state party to the Rome statute is available to reffer a matter to the Court under Article 14 of the Rome Statute of the ICC and said Article provides that:-

1. A State Party may refer to the Prosecutor a situation in which one or more crimes within the jurisdiction of the Court appear to have been committed requesting the Prosecutor to investigate the situation for the purpose of determining whether one or more specific persons should be charged with the commission of such crimes.

2. As far as possible, a referral shall specify the relevant circumstances and be accompanied by such supporting documentation as is available to the State referring the situation.

Previously, it was thought that referral by a state party will be less useful because ordinarily a state party is reluctant to initiate proceedings against its own citizens and particularly when state machinery is involved in commission of the crimes. But, later on, the first referral by Uganda and then second by Congo has proved otherwise ${ }^{49}$. Moreover, in 1973 the UN General Assembly adopted a set of principles which declared that all states were to co-operate with each other in the detection, arrest, extradition and punishment of persons guilty of war crimes and crimes against humanity ${ }^{50}$.

\section{Security Council Referral}

The second mode of triggering the jurisdiction of the ICC is through Security Council referral. However, no specific

\footnotetext{
${ }^{47}$ William A. Schabas, An Introduction to International Criminal Court, Cambridge, Cambridge University Press, (2007), 82-83.

48 Ibid, 87-88.

49 Ibid, 145.

50 Edited by

MARK LATTIMER

and

PHILIPPE SANDS, Justice for Crimes

Against Humanity, (Portland, Oregon: Hart Publishing, 2003), 5.
} 
provision has been provided for the same and this is primarily governed by Article 13(b) of the Rome Statute of the $\mathrm{ICC}^{51}$.

\section{Proprio Motu of the Prosecutor}

Giving the prosecutor power to investigate a crime allegedly committed was a controversial aspect and such power was not given to the prosecutor by the International Law Commission upon the objections by some states such as the USA. But some other people have stated that the issue would involve complications and restricting the jurisdiction of the ICC by state or Security Council referral would be a hurdle for meeting the proper ends of justice ${ }^{52}$.

\section{Deferral of Jurisdiction}

Mechanism for deferral of jurisdiction has been provided under Article 16 of the Statute. Said Article provides that:-

No investigation or prosecution may be commenced or proceeded with under the Statute for a period of 12 months after the Security Council, in a resolution adopted under Chapter VII of the Charter of the United Nations, has requested the Court to that effect; that request may be renewed by the Council under the same conditions.

The logic behind inserting this Article has been described that such deferral may be necessary for maintaining the peace and security, for which the Security Council has been tasked with, because preventing the prosecution of an individual will cause lesser harm if instead of that peace and security is maintained. In this respect, requests were made by Uganda, and then Sudan against its president separately but both of them remained unsuccessful ${ }^{53}$.

\section{Enforcement of ICC}

Lastly, the most important of all and the outcome of discussion is the enforcement of the verdicts of the Court. Under the domestic system enforcement mechanism is provided in the shape of police. Under the Rome Statute such mechanism has been provided under part 9 of the Statute. Article 89 of the Statute imposes liability upon the state parties to surrender any person present within the territorial jurisdiction of such state party whenever such request has been made. International organizations may also be requested to provide such assistance under Article 87 of the Statute. However, no party is bound to provide imprisonment facilities and the ICC may select any state party for such assistance from within the list of the state parties showing their willingness for the same ${ }^{54}$.

However, it is yet to be established that international trials will make dictators 'think again' and deter the commission of future crimes against humanity ${ }^{55}$. If any state fails to

\footnotetext{
${ }^{51}$ William A. Schabas, An Introduction to International Criminal Court, Cambridge, Cambridge University Press, (2007), 151.

52 Ibid, 159

53 Robert Cryer, Hakan Friman, Darryl Robinson, Elizabeth Willmshurts, An Introduction to International Criminal Law and Procedure, 169-170.

54 Ibid, 170.

55 Edited by MARK LATTIMER and PHILIPPE SANDS, Justice for
}

comply with the directions, matter may be referred to the Assembly of the state parties or the Security Council. However, the former cannot impose mandatory requirement and the later may, in accordance with the Charter of the United Nations ${ }^{56}$.

The final outcome of the above-mentioned discussion is that a positive, effective and fruitful step has been taken with the promulgation of the Rome Statute and the emergence of the International Criminal Justice System. However, the task is not yet over. There are number of complications in implementation of the mechanism already provided, and for the improvement in the available mechanism and the same cannot be done without taking together the entire international community and the cooperation on behalf of international community depreciating the personal interests of the powerful states and taking the weaker states on equal footings.

\section{REFERENCES}

[1] Abass, A., 'The Competence of the Security Council to Terminate the Jurisdiction

[2] Abtahi, Hirad, 'The Islamic Republic of Iran and the ICC', (2005) 3 Journal of International Criminal Justice 635.

[3] Adam Jones, Genocide: A Comprehensive Introduction, Park Square: Routledge, 2006.

[4] Ailslieger, Kristafer, 'Why the United States Should Be Wary of the International Criminal Court: Concerns over Sovereignty and Constitutional Guarantees', (1999) 39 Washburn Law Journal 80.

[5] Butler, A. Hays, 'A Selective and Annotated Bibliography of the International Criminal Court', (1999) 10 Criminal Law Forum 121

[6] Byron, Christine, 'Genocide', in Dominic McGoldrick, Peter Rowe and Eric Donnelly, eds., The Permanent International Criminal Court: Legal and Policy Issues, Oxford and Portland, OR: Hart Publishing, 2004, pp. 143-77.

[7] Byron, Christine, and Turns, David, 'The Preparatory Commission for the International Criminal Court', (2001) 50 International and Comparative Law Quarterly 420.

[8] Caflisch, Lucius, 'The Rome Statute and the European Convention on Human Rights', (2002) 23 Human Rights Law Journal 1.

[9] Caianiello, M., 'From the International Criminal Tribunal for the Former Yugoslavia to the International Criminal Court', (2001) 26 North Carolina Journal of International Law and Commercial Regulation 408.

[10] Ciara Damgaard, Responsibility for Core International Crimes Individual Criminal, Denmark: Springer-Verlag, 2008.

Crimes Against Humanity, (Portland, Oregon: Hart Publishing, 2003), 20.

${ }^{56}$ Robert Cryer, Hakan Friman, Darryl Robinson, Elizabeth Willmshurts, An Introduction to International Criminal Law and Procedure, 171. 
[11] Court and its Vision of World Society, New York: Oxford University Press, 2007).

[12] Ed. Larray May, Vanderbilt University and Centre for Applied Philosophy and Public Ethics, International Criminal Law and Philosophy, Cambridge, New York, Melbourne, Madrid, Cape Town, Singapore, São Paulo, Delhi, Dubai, Tokyo: Cambridge University Press, 2010.

[13] Edited by MARK LATTIMER and PHILIPPE SANDS, Justice for Crimes Against Humanity, Portland, Oregon: Hart Publishing, 2003.

[14] Friman, H., 'Rights of Persons Suspected or Accused of a Crime', in Roy S. Lee, ed., The International Criminal Court: The Making of the Rome Statute: Issues, Negotiations, and Results, The Hague: Kluwer Law International, 1999, pp. 247-62.

[15] Fronza, Emanuela, 'Genocide in the Rome Statute', in Flavia Lattanzi and William Schabas, eds., Essays on the Rome Statute of the International Criminal Court, vol. I, Ripa Fagnano Alto: Editrice il Sirente, 2000, pp. 105-38.

[16] Gaeta, Paola, "Is the Practice of "Self-Referrals" a Sound Start for the ICC?', (2004) 2 Journal of International Criminal Justice 949.

[17] Galasso, Mercurio, 'Appeal and Revision in Front of the International Criminal Court', in Flavia Lattanzi, ed., The International Criminal Court: Comments on the Draft Statute, Naples: Editoriale Scientifica, 1998, pp. 301-10.

[18] Jason Ralph, Defending the Society of States: Why America
Opposes the International Criminal

[19] Larry May, Aggression and Crimes against Peace, Cambridge: Cambridge University Press, 2008.

[20] Leslie Alan Horvitz and Christopher Catherwood, Encyclopedia of war crimes and genocide, New York: Facts On File, Inc, 2006.

[21] The Competence of the Security Council to Terminate the Jurisdiction of the International Criminal Court', (2005) 40 Texas International Law Journal 263.

[22] Robert Cryer, Hakan Friman, Darryl Robinson, Elizabeth Willmshurts, An Introduction to International Criminal Law and Procedure, Cambridge, Cambridge University Press, 2010.

[23] Robert Cryer, Prosecuting International Crimes: Selectivity and the International Criminal Law Regime, Cambridge, New York, Melbourne, Madrid, Cape Town, Singapore, São Paulo, Cambridge University Press, 2005.

[24] The Defence of Superior Orders: The Statute of the International Criminal Court Versus Customary International Law', (1999) 10 European Journal of International Law 172.

[25] Toward the Establishment of a Permanent International Criminal Jurisdiction', (1998) 4 International Peacekeeping Newsletter 110.

[26] William A. Schabas, An Introduction to International Criminal Court, Cambridge, Cambridge University Press, 2007 